\title{
THE TEACHING OF ENGLISH IN INDONESIAN PRIMARY SCHOOLS: A RESPONSE TO THE NEW POLICY
}

\author{
Ahmad Jazuly ${ }^{1}$ \\ IKIP PGRI Jember \\ Ninuk Indrayani ${ }^{2}$ \\ IAIN Jember \\ Nostalgianti Citra Prystiananta ${ }^{3}$ \\ IKIP PGRI Jember \\ $\underline{\text { ahmadjay2006@gmail.com }}$
}

Submit, 10-04-2019 Accepted, 21-12-2019 Publish, 22-12-2019

\begin{abstract}
In this study, I investigated the teachers' current practice without curriculum of English lesson at primary schools and teacher's response to the new policy on English lessons in primary school. The participants of this study were 46 respondents which consist of 17 males and 29 females. The data was obtained by distributing an open-ended question to teachers who teach in a primary school in Jember district of East Java. The questionnaire was administered to the teacher to be filled in directly. The first finding showed that most of the teachers agreed that teachers should be qualified, teachers need appropriate teaching media for students, and most of the students are very enthusiastic in learning English. The second finding about the teacher's response to the new policy on English lessons in primary school showed that most teachers expected the government to return the English language policy to be taught in primary school as a compulsory subject. Conclusion, the current practices of teaching English in primary school are divided into three parts, 1) most the teachers who involve become sample in this study agreed that the teachers should be qualified in teaching English in primary school, 2) most the teachers needed teaching media appropriate for the students in primary school, 3) most the students were very enthusiastic about learning English.
\end{abstract}

Keyword; Indonesian primary school, teacher, new policy.

\section{INTRODUCTION}

Teaching English in Indonesian primary school is always a challenge for some teachers since 1994 up to now. Moreover, since 2012 the government has changed the English language policy from the mandatory subject to be as a local 
subject in the national education curriculum in Indonesia. However, even English is not compulsory for the students in primary school, English is still taught from the first grade to sixth grades in their education at the primary levels. However, the role and position of English as a foreign language was still an important subject in the Education ordinance since 1994 curriculum until the new 2013 curriculum (K-13). Education policies have issued a mandate of the law. Up to now, the policies related to the curriculum of education during the reform period can be mapped into three parts: the 2004 curriculum policy of Curriculum-Based Competence (KBK), in 2006 Curriculum known as Education Unit Level Curriculum (KTSP), and 2013 Curriculum (K-13). These changes are a form of the response and development towards various changes faced both in the political, cultural, social, economic, science and technology systems (Ministry of Education and Culture, 2016)

The 2013 curriculum brings many changes to national education systems, especially English in primary schools. In accordance with government regulation in the 2016 concerning about 2013 curriculum (K-13 Revision) of the general directorate of primary and secondary education, Ministry of education and culture has regulated the decision letter number: 253/KEP.D/KR/2017 on the Establishment of Curriculum Implementation Education Unit (CIEU) 2013 in 2017 the government regulation will be used as the basic reference in the administration of teachers (Syllabus, RPS, RPP, and Instructional Analysis) and in the assessment of student results etc.

Teaching English in Indonesian primary school need qualified teachers to help students learn English better. The rule English lessons is taught in Indonesia have consequences for the quality of the program. According to teacher quality, some studies on teaching English lesson in Indonesian primary schools has declared that most teachers in Indonesian primary schools were not qualified yet and most the teachers do not have sufficient order of English teacher to be able to teach competently and effectively. The teacher education departments in some universities have given many pre-service teachers to prepare in teaching learning at SMP and SMA for many years since the national curriculum for English language education in Indonesian school focuses on SMP and SMA students. However, they have not acted the same for primary school teachers (Nur \& Munir, 2009:29)

In many places of Indonesia, English curriculum have been developed by district or provincial administrations, even though, it is happening in East Java. The local responsibility for such English lessons was defined in act letter number: 253/KEP.D/KR/2017 released by the minister of national education, which specified that local subject is used as curriculum activities to develop competencies that is adapted to the characteristics of the district. For that rational, 
the local subject curriculum in one part of Indonesian primary school could be diverse from the local subject curriculum in another district, either in terms of content or purpose (Suyanto \& Erni, 2010:78).

In many Indonesian primary schools, the English language curriculum does not have sufficient and proper facilities to support teaching and learning (Faridi, 2010:34). Many primary schools lack of instructional resources. The schools do not have visual or audio-visual aids and for teaching media, most the teachers still used blackboard, chalk and board-marker method when they are teaching English to primary students. To solve the problem of lack of teaching resources, most the teachers use Lembar Kerja Siswa (LKS) or workbook as the one of resources for their teaching learning English (Lestari, 2003:89). Many of the workbooks or textbooks available in the market are cheap and of course with low quality, as is witness by the many grammar errors, spelling and the pictures that are questionable for the primary students. The problem with the lack of resources for teaching-learning English is often connected to the school budget. Therefore, many primary schools in village cannot able to buy pictures, cards, or video because their budget is not sufficient. It means most the teachers have not good prepared for implication with the new policy.

In this study, I investigate teachers who involve in teaching English in Indonesian primary schools responds to the new policy in some primary schools in Jember district of East Java. This study presents teachers' knowing about curriculum and the teachers' current practice without curriculum of English lesson at primary schools. After analyzing data, it shows indicates that the teachers are knowledgeable to answer an important role in implementing teachers establish the policy of teaching learning English in Indonesian primary schools.

\section{LITERATUR REVIEW}

\section{Teacher Reform in Indonesia: The Role of Politics and Evidence in Policy Making}

In 2005, Indonesia implemented the teacher law to improve the quality of its teachers. Under the new law, teachers must obtain certification by completing four years college degree and continue to improve their skills. A program is supporting the government to implement the teacher quality management reform as mandated by the Teacher Law World Bank Group.

In an effort to improve education quality in Indonesia, in 2005 the government passed the Teacher Law (TL), a comprehensive bill designed to raise the quality of teachers. "I wasn't confident in teaching, because I did not understand good teaching methods. Now I am more confident and the students are more motivated to learn," said Tina Setiawati, a teacher who benefitted from training provided by a project support the implementation of the teacher law. A 
key reform required all teachers to acquire a four-year degree and be certified. Teachers who obtain certification then receive a professional allowance that effectively doubles their salary. By 2015, Indonesia's 2.7 million teachers expect to be certified.

\section{Indonesia to End Teaching of English in Primary Schools}

Students recite the Qur'an at an Islamic boarding school in Medan, North Sumatra, Indonesia. The teaching of English in Indonesia's primary schools will end next year as the government attempts to reverse falling standards in Bahasa Indonesia. Deputy education and culture minister Musliar Kasim announced an over haul of the curriculum that will see English classes cease by July, 2012. He told the Jakarta Post newspaper that students need more time to master their first language. "Elementary schools will not have English lessons because (students) haven't learned to understand the Indonesian language. Now even some kindergarten students take English courses, I pity the kids," Musliar said.

The ministry also plans to focus more teaching time on religion and Indonesian culture at the expense of science and social studies, the newspaper reported. English language classes will start from Junior High School in state schools. The move is being linked to a fall in the number of students in recent years who are passing their language high school matriculation. Another set of poor results published in May prompted some education observers to claim that students were devoting too much time to learning English at the expense of language. Others point out that the low pass rate can be blamed on poor teaching standards.

According to Zein (2016:45), said the school need a strategy to enhance the quality of parental support where as plummeting the gap resulting ffrom more prosperous parents sending their children to take private English school outside of normal class time (local content). By building stronger cooperation with schools in family language learning, she asserted that 'parents will develop a better understanding of their children's learning and become more confident in themselves as supporters of their children's English literacy education'.

The Malaysian education system aims to produce students who will be at minimum skilful in Bahasa Malaysia as the National language and language of unity, and English as the International language community. This means that upon leaving school, pupils are expected to be able to work in both a Bahasa Malaysia and English language environment. However, the current system produces commendably strong Bahasa Malasysia Learning outcomes but not the English language. There is widespread operational proficiency in Bahasa Malaysia among students, but operational proficiency in English is much lower. Hence, efforts at education reform to boost pupils' proficiency in English become the most 
immediate priority in the Standards Based English Language Curriculum for primary schools. In addition to that, changes in the new English language curriculum may it be in curriculum content or teaching approach or assessment demand teachers and students to incorporate higher order thinking skills in teaching and learning of the English language at foundation level of primary education (Sulaiman, et.al, 2015:67).

The implementation of reform successfully as planned will change the setting of English learning experiences in multilingual and plural Malaysia at micro and macro levels. With greater prominence on stadards and competencies that are closely assessed for self-achievement rather than school success, and increased contribution of parent and community including private and public sectors, an expanded ecosystem of learning is created beyond the classrooms to involve the social realities to the students' life outside of the schools (Azman, Hazita, 2012).

\section{RESEARCH METHOD}

This data was obtained by distributing an open-ended question to teachers who teach in a primary school of Jember district of East Java. There were 46 respondents which consist of 17 males and 29 females. The questionnaire was administered to the teacher to be filled in directly. The open-ended Questionnaire consists of two parts. The first part consists of eight questions that asking about the current practice of teaching English in Indonesian primary school. The second part consists of one question about the teachers' opinion regarding the new policy of teaching learning English in Indonesian primary school.

The steps of data analysis used qualitative analysis principles. First of all, after the data collected from the respondents, the data was categorized based on the need to answer the research question. After the data was categorized, the data exposure was done verbally on the part of the finding. Then the data that has been described was interpreted to provide a logical explanation. In the discussion section, findings obtained from data collection were discussed comprehensively from the point of view of government policy, curriculum and previous research findings.

\section{FINDING}

\section{The Current Practice of Teaching English in Primary School}

The findings of this study are organized into two main points based on the research questions. There were eight questions which the answers are explaining the current practices of teaching English in primary school.

First, what are the teachers' qualifications in teaching English for primary school? From 46 respondents, the teacher who has qualifications of English 
education background (EB) there are 16 teachers, and the teacher who has qualifications of English non-education background (NEB) are 30 teachers. So, most of the teachers are not qualified yet in teaching English in primary school.

Second, how long have the teachers taught in primary school? There are 25 teachers have been teaching English in primary school more than 5 years, and 21 teachers are less than 5 years in teaching English in primary school. It also revealed that teachers who have experienced more than 5 years were not graduated from English education department.

Third, how is the teacher's opinion about the position of English in primary school? From 46 respondents, there are 20 teachers said that the positions of English subject as local content in primary school and 26 teachers said that the positions of English as compulsory subjects in primary school. It means that most the teachers' opinion and perceives about the position of English as compulsory subjects more than the teachers said that English is a local content.

Fourth, in what grade does English start to be taught in primary school? From 46 respondents, 37 schools started to be taught English at first grade, and 9 schools started to be taught English at fourth grade in primary school. It means most the schools begin to teach English lesson from the first grade in primary school.

Fifth, are the English learning resources adequate in primary schools? From 46 respondents, there is 10 teachers answered that the English learning resources were adequate in their primary schools, but 36 teachers answered that English learning resources were not adequate. It means that most of the teachers said that the English learning resources were not adequate in their primary schools.

Sixth, what are teaching methods often used by teachers in primary schools? From 46 respondents, 32 teachers were teaching English by using textbook or LKS (Lembar Kerja Siswa) method in primary school, and 14 teachers were teaching English by multimedia, ICT and Computer Based Learning (MALL) methods in Indonesian primary school. It means that most teachers still teach English in a conventional way of using the textbook.

Seventh, how is students' enthusiasm towards English lessons in primary school? From 46 respondents, 40 teachers said that students were very enthusiastic in learning English, and only 6 teachers said that students were not enthusiastic in learning English. It means that most the students in primary school responsed positively toward English language teaching.

Eighth, how much time is provided in a week to learn English in primary school? From 46 respondents, there were 14 teachers answered that the duration for teaching English in primary school was about 40 minutes x 2 in a week, and 32 teachers answered that the duration for teaching English in primary school 
about 40 minutes $x 1$ in a week, so it was not enough. It means that most of the schools provided an inadequate time allocation for teaching English in primary school because the school knows that English is only local content, so that schools do not prioritize English compared to other lessons.

\section{The Teachers' Response to the New Policy on English Lesson in Primary School}

The data shows that 46 of the teacher's response to the new policy on English lessons in primary school can be described into three opinions about position of English policy in primary school.

First, most the teachers expected the government to return the English language policy to be taught in primary school as a compulsory subject. Otherwise, the teacher cannot freely develop students' potential in their school.

Second, teachers requested additional learning media suitable for English lesson in primary school. The students' competencies can improve when the students learn English with adequate English learning resources such as multimedia, VCD, LCD, Computer Based Learning (MALL) and so forth.

Third, teachers asked for training education on methods and strategies in learning English in primary school. Otherwise, the teachers need development, improvement of competency and professionalism in English teaching-learning material. If all the completeness of learning resources and training education on methods and strategies are completed, the school can apply the four elements of 2013 curriculum, include; the first Standards Graduate Competency (SGC), the second, Standards Content (SC) the third, Standards Process (SP), and the four Standards of Assessment (SA), and those all elements are complemented by a scientific approach of observing, questioning, exploring, associating, and communicating.

\section{DISCUSSION}

\section{Curriculum Policy}

The curriculum has functions and roles that are very important and strategic. Although it is not the only major factor in the success of the educational process, the curriculum becomes a guide and direction towards educational success. The curriculum guides teachers or educators and education personnel to develop their creativity and abilities in developing and describing various learning materials and tools. Therefore, good teacher or educators and education personnel are able to understand the curriculum and implement it in the learning process.

2013 Curriculum was changed in a form of development and refinement of the previous curriculum of KTSP curriculum in 2006. The emphasis of 2013 curriculum development is improving thinking, strengthening curriculum 
governance, strengthening the learning process, deepening and expanding the material, and adjusting the burden of learning in order to ensure the suitability between what is wanted with what is created. Hence, the implication of 2013 curriculum is depended to be a strategic step in preparing and deal with the challenges of digital era in the future.

\section{Elements of 2013 Curriculum Change}

The curriculum changes in 2006 to the curriculum of 2013 concerns the four elements of curriculum change, namely; the first, Standards Graduate Competency (SGC), namely the improvement and balance of soft skills and hard skills by honing 3 aspects: attitude, knowledge, and skills. The second, Standards Content (SC), namely the change of standards content where the 2006 KTSP competence derived from the subjects, the 2013 curriculum subjects derived from competence. Therefore, the approach is equally done through a subject approach. The third, Standards Process (SP), which were originally focused on exploration, elaboration, and confirmation, in the 2013 curriculum are complemented by a scientific approach of observing, questioning, exploring, associating, and communicating. The teaching learning process doesn't only take place in the classroom, but also occur out of the school, society and nature. The position of the teacher is not the only source of learning, and the learning of the attitude dimension was not taught verbally, but through examples and teacher's example. The Fourth, Standards of Assessment (SA). The assessment is competencybased; the displace from assessment through test measuring competence and knowledge on the basis of outcome to the authentic assessment of attitudes, skills, and knowledge based on the process and outcome. Strengthening the assessment model (Reference of Benchmark Assessment) is the achievement of learning outcomes based on the position of the scores obtained against ideal score (maximum), and promote the use of portfolios or tasks made by students as the one instrument of assessment.

\section{CONCLUSION}

The current practices of teaching English in primary school are divided into three parts. The first, most the teachers who involve become sample in this study agreed that the teachers should be qualified in teaching English in primary school. The second, most the teachers needed teaching media appropriate for the students in primary school. The third, most the students were very enthusiastic about learning English. 


\section{REFERENCES}

Azman, H. (2012). Implementation and Challenges of English Language Education Reform in Malaysian Primary Schools. The Southeast Asian Journal of English Language Studies, 22(3), 65-78.

Devina, N \& Munir, A. (2009). English Language Teaching Challenges in State Vocational High Schools in. 1-6.

Faridi, A. (2010). The Development of Context-Based English Learning Resources for Elementary Schools in Central Java. 1, 23-30. https://doi.org/10.5195/ehe.2010.13

Suyanto \& Kasihani, E. (2010). Pengajaran Bahasa Inggris di Sekolah Dasar: kebijakan, implementasi, dan kenyataan. (c), 2-6.

Lestari, L., A. (2003). Should Eng be a cumpolsory subject in primary school.pdf. Bahasa Dan Seni, 31(2), 197-213.

Ministry of Education and Culture. (2016). The Management of National Education in Year 2014/2015 at a Glance. 124. Retrieved from http://publikasi.data.kemdikbud.go.id/uploadDir/isi_ _ 6549DA84-7A7F44B5-AD22-829B1F002A4F_.pdf

Sulaiman, T., Fauzi, A., \& Ayub, M. (2015). Curriculum Change in English Language Curriculum Advocates Higher Order Thinking Skills and Standards-Based Assessments in Malaysian Primary Schools. Mediterranean Journal of Social Science, 6(2), 494-500. https://doi.org/10.5901/mjss.2015.

Zein, M., S. (2016). Elementary English education in Indonesia: Policy developments , current practices, and future prospects. English Today, 17. https://doi.org/10.1017/S0266078416000407 